\title{
Reflections on collective versus individual rights related to communicable diseases
}

\author{
Maria Clara Padoveze', Núbia Virginia D'Avila Limeira de Araujo ${ }^{1}$ \\ ${ }^{1}$ Universidade de São Paulo, Escola de Enfermagem, Departamento de Enfermagem em Saúde Coletiva, São Paulo, SP, Brazil. \\ E-mail: padoveze@usp.br
}

How to cite this article:

Padoveze MC, Araujo NVDAL. Reflections on collective versus individual rights related to communicable diseases. Rev Esc Enferm USP. 2017;51:e03220. DOI: http://dx.doi.org/10.1590/S1980-220X2017000003220

On January 19, 2017, the Centers for Disease Control and Prevention (CDC), within the Department of Health and Human Services (HHS), United States, published a new regulation, which since its conception reignited old controversies between collective and individual rights. This provision includes amendments to current legislation for the management of communicable diseases within the scope of public health protection, which among other measures, determines quarantine of individuals believed to be infected. The rule, effective as of February 21,2017, expands CDC's powers to apprehend individuals suspected of having a quarantinable disease, under conditions that can be instituted based on more generic symptoms, such as high fevers, for example ${ }^{(1)}$.

According to the CDC, quarantine "separates and restricts the movement of people who were exposed to a contagious disease to see if they become sick"; and isolation "separates sick people with a contagious disease from those who are not sick ${ }^{(2)}$."Isolation and quarantine are recognized worldwide as being based on scientific evidence and as effective practices to prevent the dissemination of diseases that are transmitted through direct person-to-person contact $^{(3)}$. Notwithstanding, the controversy regarding the conditions of their application and indications is one of the most emblematic issues in the conflict between individual and collective rights in the field of epidemic control.

Quarantine is directed at individuals who have not yet presented as clinically ill, which makes it difficult to establish exact criteria for its indication. When pertinent, implementing quarantine can be a significant tool to protect public health. However, when not pertinent, it can result in harmful effects, among them isolating people from social contact, creating stigma, preventing workers from producing and consuming goods and services, and generating social and economic impacts. Furthermore, the improper use of quarantine can generate a perception of insecurity in society, due to unnecessary alarm, a sense of invasion of privacy, and violation of rights.

In this context, we highlight the lessons learned from the avian influenza and Ebola virus disease epidemics, and recent outbreaks of Middle East respiratory syndrome caused by the coronavirus (MERS-Cov). These episodes reinforce the need to improve the capacity of countries to ensure rapid response in the event of epidemics ${ }^{(4)}$, while also highlighting the controversy about the use of quarantine and other restrictive measures in these situations ${ }^{(5-7)}$.

Even before the amendments proposed by the $\mathrm{CDC}$, the review of the International Health Regulations (IHR) in 2005 helped revive the discussion. The emergence and re-emergence of diseases and the increased risk of propagation given the growing level of travel and trade around the world motivated the IHR to be reviewed. This process began in 1995 and was only completed 10 years later, at the $58^{\text {th }}$ World Health Assembly in 2005, entering into force in June $2007^{(3)}$.

The global perspectives are toward the development of coordinated actions among countries involved in emergencies of international repercussions, and the importance to collective health, in order to stop diseases from spreading (in addition to classic prevention measures, rapid production of vaccines and specific tests, for example). Signatory countries are committed to adopting the IHR in full, and the World Health Organization has been monitoring such compliance ${ }^{(8)}$. However, considering the right to sovereignty, countries can adopt different positions when implementing the IHR, adapting national instruments and laws, providing they respect international agreements. In the case 

the resolution currently in force, based on a framework of disease epidemiology.

During the public consultation phase of this new resolution, the CDC received manifestations that demonstrated controversies, among them the conflict between collective and individual rights. People also voiced concerns about the actual process of quarantine application, which included questions about the technical criteria used for its indication. Such questions, the reviews made to the document, and their justifications can be found in the final version of the published regulation ${ }^{(1)}$.

However, what we emphasize here is that, while minimizing the risk of spreading illness is a historically demonstrated international urgency, the universally accepted postulates of human right cannot be neglected. Thus, achieving balance between them is a contemporary challenge of utmost importance. This is the conflict that is yet to be resolved: Does the state have the right to confine individuals to preserve collective health? In name of the preservation of individual rights, can a person expose others to the risk of contagion? This is a field in which human rights and health rights seek common ground. The adoption of sanitary control measures that restrict liberties has long represented a complex issue, given the aspects involved. These are not limited to their technical nature, but also include political, social, and economic aspects, as such measures impact the health conditions of entire populations ${ }^{(9)}$. Consequently, it is essential to promote dialogue among policymakers, society, and professionals.

The historical process of managing and preventing communicable diseases, particularly those that are prone to cause epidemics and pandemics, has shown that they do not respect political and geographical borders of municipalities, states and countries. In this context, it is unlikely that any sole country can take isolated measures that can be considered fully protective, as contemporary dynamics involves the constant flow of goods and persons, leading to the natural rupture of protection bubbles. Thus, the global trend indicates cooperation among people as a solution and the need for evidencebased consensus and respect for the principles of ethical social coexistence.

The contribution of society to this debate is essential in order to advance in the management of problems and health situations. Health social movements and social control through collegiate agencies, experimented in the past with greater intensity, or new mechanisms of social participation, are crucial for a critical stance towards the theme at hand ${ }^{(10)}$.

Health professionals are the first to be affected by public health emergencies. They are on the frontlines of care and are responsible for making decisions under conditions of physical stress and social pressure. Furthermore, they are disproportionally more affected by certain epidemic diseases due to their working conditions than the population at large. For this reason, it is essential that these professionals understand the ethical, legal and public health framework that informs their autonomy when indicating individuals for quarantine or isolation.

Historically, nurses have been engaged in minimizing vulnerability to communicable diseases. Since its onset, the profession has been deeply involved with issues related to direct care, transmission prevention, and policymaking ${ }^{(11)}$.

In practice, nurses should be committed to technical excellence coupled with protection of human rights. Moreover, especially at the present time, it is necessary that nurses work with policymaking and execution, defending the rights of individuals and families, and seeking to achieve balance between collective and individual rights. This participation is possible through political mobilization and the unrelenting defense of transparent public communication in all stages of policymaking, but also by conducting research that contributes to the production of scientific evidence that supports decision making in health.

\section{REFERENCES}

1. Centers for Disease Control and Prevention; Department of Health and Human Services, Control of Communicable Diseases. 42 CFR Parts 70 and 71. Federal Register 2017; Jan 19;82(12):6890-978. [CDC Docket No. DC-20160068]. RIN 0920-AA63.

2. Centers for Diseases Control and Prevention. Quarantine and isolation [Internet]. Atlanta: CDC; 2017 [cited 2017 Feb 01]. Available from: https://www.cdc.gov/quarantine/

3. World Health Organization. International Health Regulation (2005) [Internet]. Geneva: WHO; 2008 [cited 2017 Feb 01]. Available from: http://www.who.int/ihr/publications/9789241596664/en/

4. WHO Ebola Response Team, Agua-Agum J, Allegranzi B, Ariyarajah A, Aylward R, Blake IM, Barboza P, et al. After Ebola in West Africa: unpredictable risks, preventable epidemics. N Engl J Med. 2016;375(6):587-96.

5. Webb A. Quarantine, isolation, and health care workers. Continuum (Minneap Minn). 2015 Dec;21(6 Neuroinfectious Disease):1745-50. 
6. Smith MJ, Bensimon CM, Perez DF, Sahni SS, Upshur RE. Restrictive measures in an influenza pandemic: a qualitative study of public perspectives. Can J Public Health. 2012;103(5):e348-52.

7. Upshur RE. Evidence and ethics in public health: the experience of SARS in Canada. N S W Public Health Bull. 2012;23(5-6):108-10.

8. World Health Organization. Checklist and indicators for monitoring progress in the development of IHR core capacities in States Parties [Internet]. Geneva: WHO; 2013 [cited 2017 Feb 01]. Available from: http://www.who. int/ihr/checklist/en/

9. Barradas RB. Ética e epidemiologia. Hist Ciênc Saúde Manguinhos. 2005;12(3):735-53.

10.Silva CV, Silva DFL, Souza EM. A participação da sociedade civil na democratização do Setor de Saúde no Brasil. Rev Bras Educ Med. 2013;37(2):254-9.

11.Gill CJ, Gill G. Nightingale in Scutari: her legacy reexamined. Clin Infect Dis. 2005; 40(12):1799-805. 